\title{
Metal hydride hydrogen storage tank for fuel cell utility vehicles
}

\author{
Mykhaylo Lototskyy ${ }^{a, *}$, Ivan Tolj ${ }^{b}$, Yeugeniy Klochko ${ }^{a}$, \\ Moegamat Wafeeq Davids ${ }^{a}$, Dana Swanepoel ${ }^{c}$, Vladimir Linkov ${ }^{a}$ \\ ${ }^{a}$ HySA Systems Competence Centre, South African Institute for Advanced Materials Chemistry (SAIAMC), \\ University of the Western Cape, Bellville 7535, South Africa \\ ${ }^{\mathrm{b}}$ University of Split, Faculty of Mechanical Engineering and Naval Architecture, Department of Thermodynamics and \\ Heat Engines, Split 21000, Croatia \\ c TF DESIGN (Pty) Ltd., Stellenbosch 7600, South Africa
}

\section{A R T I C L E I N F O}

\section{Article history:}

Received 23 January 2019

Received in revised form

3 April 2019

Accepted 12 April 2019

Available online 4 May 2019

\section{Keywords:}

Hydrogen storage

Metal hydrides

Fuel cell utility vehicles

\begin{abstract}
A B S T R A C T
The "low-temperature" intermetallic hydrides with hydrogen storage capacities below $2 \mathrm{wt}$ $\%$ can provide compact $\mathrm{H}_{2}$ storage simultaneously serving as a ballast. Thus, their low weight capacity, which is usually considered as a major disadvantage to their use in vehicular $\mathrm{H}_{2}$ storage applications, is an advantage for the heavy duty utility vehicles. Here, we present new engineering solutions of a $\mathrm{MH}$ hydrogen storage tank for fuel cell utility vehicles which combines compactness, adjustable high weight, as well as good dynamics of hydrogen charge/discharge. The tank is an assembly of several $\mathrm{MH}$ cassettes each comprising several $\mathrm{MH}$ containers made of stainless steel tube with embedded (pressed-in) perforated copper fins and filled with a powder of a composite $\mathrm{MH}$ material which contains $A_{2}$ - and $A_{5}$-type hydride forming alloys and expanded natural graphite. The assembly of the $\mathrm{MH}$ containers staggered together with heating/cooling tubes in the cassette is encased in molten lead followed by the solidification of the latter. The tank can provide $>2 \mathrm{~h}$ long $\mathrm{H}_{2}$ supply to the fuel cell stack operated at $11 \mathrm{kWe}\left(\mathrm{H}_{2}\right.$ flow rate of $\left.120 \mathrm{NL} / \mathrm{min}\right)$. The refuelling time of the $\mathrm{MH}$ tank $\left(\mathrm{T}=15-20^{\circ} \mathrm{C}, \mathrm{P}\left(\mathrm{H}_{2}\right)=100-150 \mathrm{bar}\right)$ is about $15-20 \mathrm{~min}$.
\end{abstract}

๑ 2019 Hydrogen Energy Publications LLC. Published by Elsevier Ltd. All rights reserved.

\section{Introduction}

Compact, low energy consuming and safe hydrogen storage is vital to successful implementation of efficient and environment friendly hydrogen and fuel cell technologies in a number of stationary, portable and mobile applications. Various methods of hydrogen densification via compression, liquefaction or interaction with liquid- or solid-state hydrogen storage materials are in focus of international R\&D activities for the advancement of hydrogen and fuel cell power systems [1-6].

Metal hydrides $(\mathrm{MH})$ formed by a reversible reaction of gaseous $\mathrm{H}_{2}$ with a parent hydride forming metal, alloy or intermetallic compound are promising solid-state hydrogen storage materials for various end-user applications. The use of $\mathrm{MH}$ allows to achieve a very high volumetric hydrogen storage density, exceeding $100 \mathrm{gH} / \mathrm{L}$ in a unit volume of solid-state storage material $[3,6,7]$. Modest $\mathrm{H}_{2}$ equilibrium pressures at

\footnotetext{
* Corresponding author.

E-mail address: mlototskyy@uwc.ac.za (M. Lototskyy). 
ambient temperatures in combination with endothermic nature of the $\mathrm{MH}$ decomposition result in high intrinsic safety of MH-based hydrogen storage systems. Finally, the ability of extremely broad variation of thermodynamic characteristics of the hydrogen - metal systems by the variation of the composition of the parent material allows to achieve exceptional flexibility of the MH based systems which can be used for hydrogen storage and its controlled supply at pressure/ temperature conditions suitable for the customer needs [6-8]. Due to unique combination of their properties, $\mathrm{MH}$, in addition to hydrogen storage, are also used in a number of related applications including thermally driven $\mathrm{H}_{2}$ compression, thermal management, etc. [8].

The use of fuel cells (FC) in heavy duty utility vehicles, including material handling units/forklifts, has a number of advantages over similar battery-driven vehicles including: (i) constant power during the entire shift, and (ii) shorter refuelling time as compared to the time required to recharge the battery $[7,9,10]$.

Most of the fuel cell power systems for forklifts demonstrated so far have utilised compressed hydrogen stored in gas cylinders (CGH2) at pressures up to 350 bar [11]. However, in comparison to lead-acid batteries, which are conventionally used in the electric forklifts, all commercially available forklift fuel cell power systems with CGH2 hydrogen storage tanks [12-14] are too light and require additional ballast for a proper counterbalancing to provide vehicle stability when lifting rated loads.

The application of $\mathrm{MH}$ for hydrogen storage in the fuel cell powered forklifts $[8,10,15]$ and similar utility vehicles (e.g., underground mining vehicles [16]) is a promising option. The "low-temperature" intermetallic hydrides with hydrogen storage capacities below $2 \mathrm{wt} \%$ (i.e. storage of $1 \mathrm{~kg} \mathrm{H}$ requires more than $50 \mathrm{~kg}$ of the $\mathrm{MH}$ material) can provide compact $\mathrm{H}_{2}$ storage simultaneously serving as a ballast. Thus, the low weight capacity of intermetallic hydrides, which is usually considered as a major disadvantage to their use in vehicular hydrogen storage applications [1,2], is an advantage for the heavy duty utility vehicles $[7,10]$. The use of metal hydrides for the storage of hydrogen fuel, where the $\mathrm{MH}$ additionally serves as a ballast/counterweight, was described in a number of patents [17-20]. General features of these solutions include placement of a metal hydride hydrogen storage material in a plurality of metal hydride containers which supply hydrogen fuel to a hydrogen engine or fuel cell and are equipped with a means for their heating to provide $\mathrm{H}_{2}$ desorption from the metal hydride by transferring the heat released during the engine or fuel cell operation to the $\mathrm{MH}$ containers.

A metal hydride hydrogen storage tank for forklift applications was developed by Hawaii Hydrogen Carriers LLC, together with other companies and institutions [21]. The tank is made as a staggered array of tubular containers filled with an $\mathrm{AB}_{5}$-type $\mathrm{MH}$ material and placed in a water tank. The hydride tank has dimensions $470 \mathrm{~mm}$ (L) x $700 \mathrm{~mm}$ (W) $\mathrm{x}$ $370 \mathrm{~mm}(\mathrm{H})$, contains about $2 \mathrm{~kg}\left(\sim 20 \mathrm{Nm}^{3}\right) \mathrm{H}_{2}$ and has an estimated weight about $500 \mathrm{~kg}$ when filled with water. The tank, together with other components of the fuel cell power module, was integrated in Crown electric forklift with lifting capacity of $5000 \mathrm{lb}$ ( 2.3 tonnes). To provide sufficient counterweight, all the components were assembled within rectangular metal casting body, and the most of its internal volume was occupied by the MH tank.

As it can be seen from the example presented above, main challenge of a conventional solution ( $\mathrm{MH}$ containers in a water tank) is still insufficient system weight/too big size of the $\mathrm{H}_{2}$ storage system leaving too small space for the placement of the fuel cell and its Balance of Plant (BoP). The cramped placement of the latter, in turn, creates problems in the access to the components during their assembling and service. As a rule, for even minor service or repair works, the heavy $(\sim 2$ tonnes) fuel cell power module must be taken away from a vehicle and partially disassembled.

In this work, we present engineering solutions [22,23] of a $\mathrm{MH}$ hydrogen storage tank for FC utility vehicles which combines compactness, adjustable high weight, as well as good dynamics of hydrogen charge and discharge.

\section{Layout features and performance}

\section{Metal hydride material}

Fig. 1 shows pressure-composition isotherms of a $\mathrm{C} 14-\mathrm{AB}_{2}$ Laves-type alloy $\left(\mathrm{A}=\mathrm{Ti}_{0.55} \mathrm{Zr}_{0.45} ; \mathrm{B}=\mathrm{Fe}+\mathrm{Cr}+\mathrm{Mn}+\mathrm{Ni}\right)$ used in this application, as well as in the earlier developments of $\mathrm{MH}$ hydrogen storage units at HySA Systems [24,25]. At the room temperature the alloy has an equilibrium $\mathrm{H}_{2}$ absorption pressure below 10 bar, but due to the necessity to provide a reasonably short refuelling time during $\mathrm{H}_{2}$ charge, the applied pressure should be higher. The material has a very low absolute value of hydrogenation enthalpy $\left(\Delta \mathrm{H}=-18.5 \mathrm{~kJ} / \mathrm{mol} \mathrm{H}_{2}\right.$; $\left.\Delta S=-78.1 \mathrm{~J} /\left(\mathrm{mol} \mathrm{H}_{2} \mathrm{~K}\right)\right)$ thus minimizing the heat release during the refuelling and heat absorption during $\mathrm{H}_{2}$ supply to the FC stack. The alloy exhibits reversible $\mathrm{H}_{2}$ storage capacity at the typical operating conditions about $170 \mathrm{NL} \mathrm{H}_{2} / \mathrm{kg}$ (see Fig. 1).

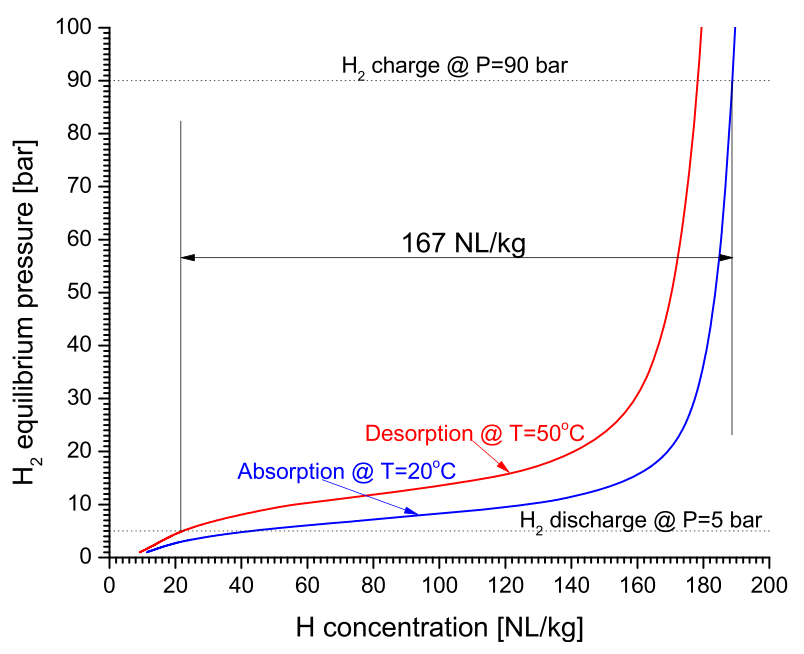

Fig. 1 - Hydrogen absorption and desorption isotherms for the $\mathrm{AB}_{2}$-type hydrogen storage alloy used in the $\mathrm{MH}$ tank. The isotherms were plotted on the basis of the experimental data further processed by a model [26]. 
The $\mathrm{AB}_{2}$-type alloy loaded in the tank as a non-activated coarse powder (particle size up to $1 \mathrm{~mm}$ ) additionally contained $10 \mathrm{wt} \%$ of $\mathrm{La}_{0.8} \mathrm{Ce}_{0.2} \mathrm{Ni}_{5}$ to facilitate its activation.

\section{Metal hydride container}

In this development, we upgraded a basic design of the $\mathrm{MH}$ container previously developed for the $\mathrm{MH}$ hydrogen storage extension tank for commercial forklift fuel cell power module [9]. The container was made of a standard SA 312 sch 40 TP316 1.5 inch seamless tube $(\mathrm{OD}=48.26 \mathrm{~mm}$, WT $=3.68 \mathrm{~mm}$, $\mathrm{L}=738 \mathrm{~mm}$ ) welded to forged SS 316 end caps. The front end cap additionally comprised an 1/4" OD SS 316 pipeline for $\mathrm{H}_{2}$ input/output, with a short tubular sintered stainless steel filter ( $0.5 \mu$ grade) welded to its end and plugged by welding from the other side. The end with the filter was inserted into the $\mathrm{MH}$ container (depth about $60 \mathrm{~mm}$ ) using a bored-through compression fitting attached to the front end cap by welding. In doing so, the container was made as all-welded stainless steel structure rated for $\mathrm{H}_{2}$ pressures up to 185 bar at temperatures up to $150^{\circ} \mathrm{C}$ and allowing a short-term heating to $\leq 500{ }^{\circ} \mathrm{C}$ when not pressurised.

For the improvement of heat transfer inside the $\mathrm{MH}$ bed, the container was equipped with internal perforated copper fins firmly pressed into the tube at $5 \mathrm{~mm}$ spacing. The $\mathrm{MH}$ powder additionally contained $1 \mathrm{wt} \%$ of expanded natural graphite (ENG) for further improvement of heat transfer in combination with protection of walls of the containment against stresses which appeared due to swelling of the $\mathrm{MH}$ particles in the course of hydrogenation and were absorbed by the ENG additive. As distinct from conventionally used solutions which provide pre-compacting of the MH - ENG composites before their loading in the container as pellets $[27,28]$, in our case the formation of "compacted" $\mathrm{MH}$ bed was achieved by the forces generated during the first hydrogenation due to volume increase of the parent $\mathrm{MH}$ material, after optimisation of characteristic inner dimensions of the $\mathrm{MH}$ container, ENG content and MH filling density [22].

The powder $(\sim 3 \mathrm{~kg})$ was loaded in the container (void volume about $0.94 \mathrm{~L}$ ) before the welding of the front end cap. The facilitation of mass transfer along the $\mathrm{MH}$ bed was provided by an auxiliary tubular gas filter plugged from both ends and installed on the axis of the internal space of the container.

According to South African safety regulations [29], the developed $\mathrm{MH}$ containers fall into SEP (sound engineering practice) category. At the same time, the following safety measures have been undertaken during its in-house design and post-manufacturing tests:

- design according to ASME 8 Div 1;

- X-ray tests of all weld joints performed on each container (40 pieces in total);

- pressure test of each container with $\mathrm{N}_{2}$ ( $P=240$ bar) witnessed by an approved inspection authority.

According to further test results, the $\mathrm{MH}$ containers had hydrogen storage capacity about $0.5 \mathrm{Nm}^{3} \mathrm{H}_{2}$ each; the charge time of the container cooled in a circulated water bath ( $\mathrm{T}=20^{\circ} \mathrm{C}$ ) was below $10 \mathrm{~min}$ at $\mathrm{H}_{2}$ supply pressure of 60 bar. Further optimisation of the $\mathrm{AB}_{2}$-type $\mathrm{MH}$ material, by introducing $\mathrm{V}$ and reduction of Fe content balanced with $\mathrm{Mn}$ from the B-side, as well as increase of Ti:Zr ratio from the Aside to $0.85: 0.15$ [25] allowed us to increase the $\mathrm{H}_{2}$ storage capacity by $24 \%$ at the same conditions. The optimised material will be used for similar applications on the later stage because its development was completed already after the series of $40 \mathrm{MH}$ containers for the hydrogen storage tank described in this work and loaded with the non-optimised $\mathrm{AB}_{2}$ alloy (Ti: $\mathrm{Zr}=0.55: 0.45$, no V) has been manufactured.

\section{MH cassette}

According to our solution [23], the hydrogen storage tank for utility vehicle applications comprises of several $\mathrm{MH}$ cassettes formed by an assembly of the $\mathrm{MH}$ containers staggered together with heating/cooling tubes encased in a molten metal or alloy (further solidified). Importantly, the metal or alloy (e.g. lead) should combine high density with melting/ solidification point below the maximum allowed operation temperature of the metal hydride container but above the activation temperature of the loaded metal hydride material.

A schematic layout of the MH cassette is presented in Fig. 2, top.

The cassette (10) comprises of five $\mathrm{MH}$ containers (11; see previous section in more details) connected to gas manifold (12) which is ended by an external pipeline (13; SS 316, 1/4" OD). Heating/cooling accessories (14) are made of pieces of $1 / 2$ " OD stainless steel tubing placed in between the containers 11 , connected in sequence and ended by pipelines $(15,16)$ for the input and output of a heating/cooling fluid (water or water-glycol mixture). The components are located within a filling body (17) formed by the solidification of molten lead.

Fig. 2, bottom, shows image of the pre-assembled $\mathrm{MH}$ cassette before lead encasing. The components 11 and 14 of the cassette (the numbering corresponds to Fig. 2, top) are placed in a removable pre-assembly case $(18)^{1}$ opened from the top and made of stainless steel sheets; all the gaps in the case 18 were closed with a heat-resistant sealant.

Fig. 3 illustrates the procedure of the lead encasing carried out at a specialised foundry. The empty space of the case (18 in Fig. 2, bottom) was filled by a pre-melted lead followed by the solidification and cooling. Importantly, during the lead encasing, the inner space of the $\mathrm{MH}$ containers has to be permanently evacuated via a shut-off valve (19 in Fig. 2, bottom) installed at the end of the gas pipeline (13 in Fig. 2). After cooling the cassette down, the evacuation was followed by introducing a pressurised argon, to protect the $\mathrm{MH}$ material activated during the lead encasing against oxidation with ambient air (e.g., after accidental opening of the valve 19 disconnected from the evacuation line) that can result in the loss of hydrogen sorption properties of the material.

Typical sequence of the operations during lead encasing (Fig. 3) is described below:

\footnotetext{
${ }^{1}$ We note that target weight of the cassette $(\sim 150 \mathrm{~kg}$ in our case) can be adjusted at the design stage by a variation of the length of the filling body (17) determined by the length of case (18) which can cover main components of the cassette $(11,12,14)$ either completely or partially.
} 

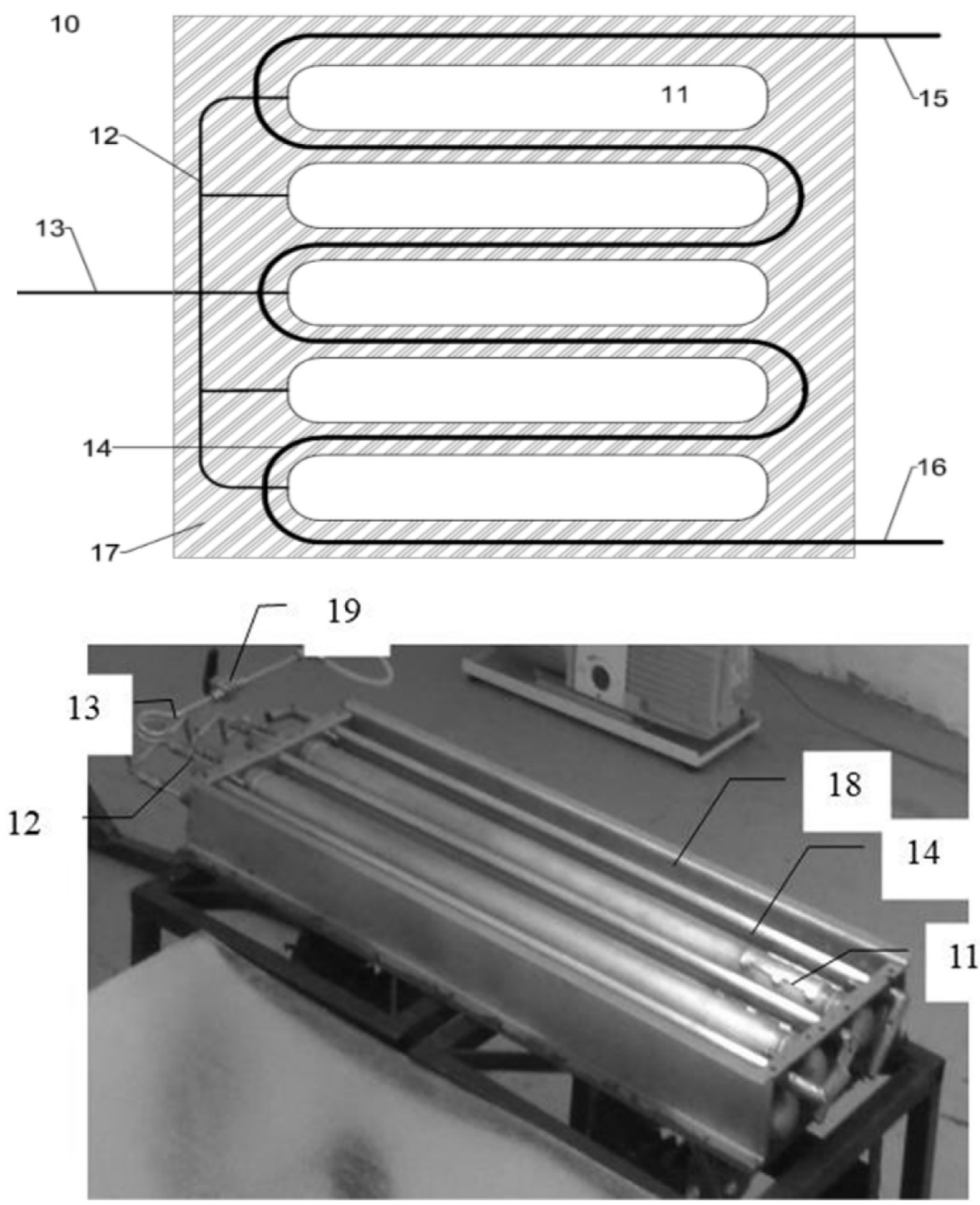

Fig. 2 - Top: schematic layout of the MH cassette [23], bottom: pre-assembled MH cassette before lead encasing.

a. Pre-evacuation of a cold pre-assembly to $10^{-2}$ mbar.

b. Pre-heat of the assembly up to $\sim 170{ }^{\circ} \mathrm{C}$ (the temperature was measured by a K-type thermocouple built into cassette, also assisted by optical pyrometer) during $20 \mathrm{~min}$. c. Casting of the pre-melted lead $\left(\mathrm{T} \sim 350^{\circ} \mathrm{C}\right)$ into pre-assembly case (18 in Fig. 2, bottom) during $10 \mathrm{~min}$. When carrying out stages $b$ and $c$, the pressure in the evacuated system increased to 2 mbar (due to desorption of gas and vapour

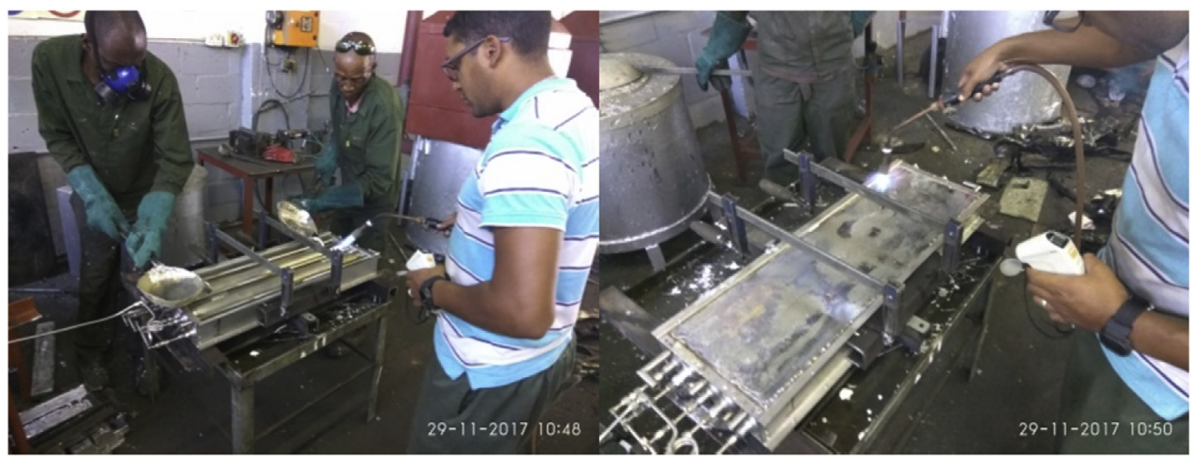

Fig. 3 - Lead encasing. 


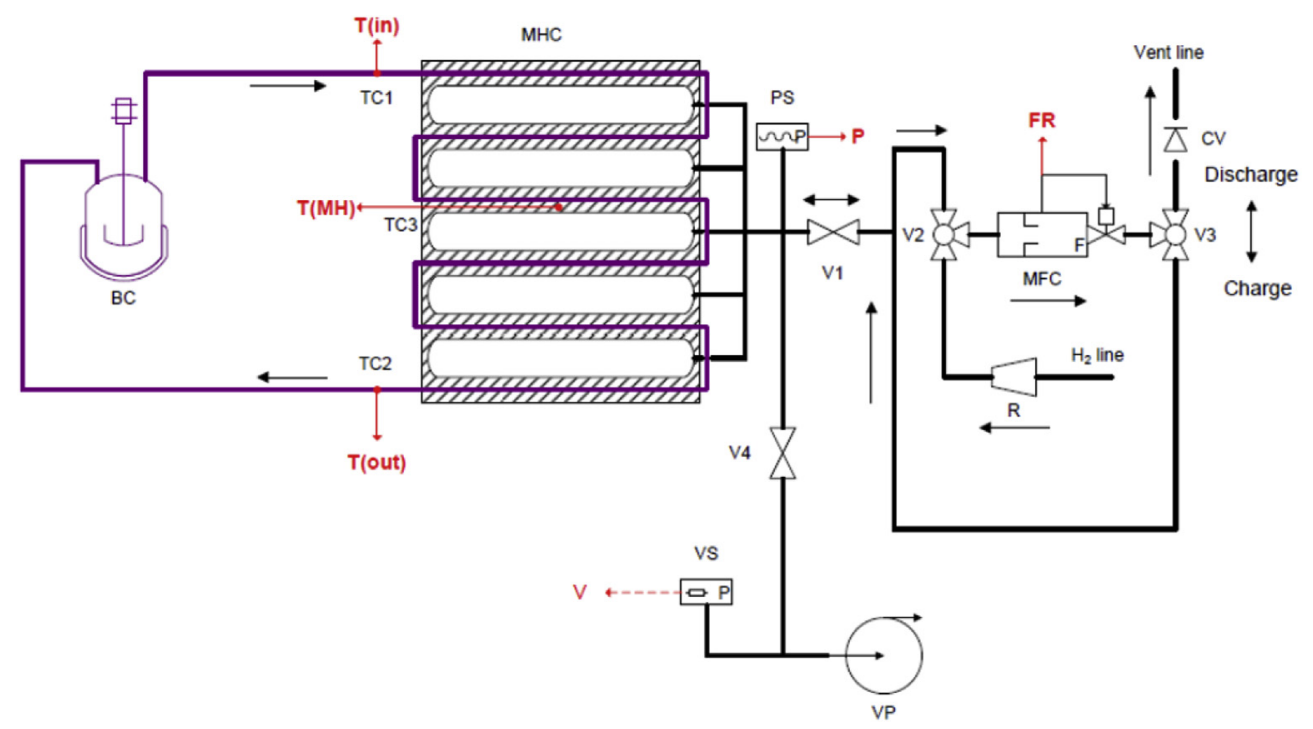

Fig. 4 - Schematic diagram of the setup for final activation and testing of the MH cassette.

species adsorbed on the inner surface of the MH containers, as well as on the particles of the MH load) followed by a gradual decrease to 0.1 mbar before the end of the lead casting.

d. Continuing the evacuation during the cooling of the cassette filled with lead down to $\mathrm{T} \sim 90^{\circ} \mathrm{C}$. The vacuum at this point was better than $5 \cdot 10^{-2}$ mbar.

e. Filling the cassette with pressurised ( 50 bar) argon.

f. After cooling the lead encased and argon-filled cassette to the room temperature and its moving from the lead encasing foundry to HySA Systems, the case (18 in Fig. 2, bottom) was removed, and the cassette $(960 \times 269 \times 88$ $\mathrm{mm}$; weight $144 \mathrm{~kg}$ ) was connected to a setup for performing the final activation procedure. ${ }^{2}$ Further details will be presented below.

Fig. 4 shows piping diagram of the setup for final activation and testing of the $\mathrm{MH}$ cassettes. The gas pipeline of the cassette is connected to a gas manifold of the setup equipped with a pressure sensor (PS; 0-250 bar) and connected, via shut-off valves V1 and V4 to $\mathrm{H}_{2}$ charge/discharge and evacuation systems, respectively. The $\mathrm{H}_{2}$ charge/discharge system includes mass flow controller (MFC; $0-50 \mathrm{NL} \mathrm{H}_{2} / \mathrm{min}$ ) and two remotely controlled 3-way valves (V2 and V3). Depending on the positions of the valves V2 and V3, an operator can switch between Charge and Discharge modes; in both cases a unidirectional hydrogen flow via mass flow controller (MFC) is provided. In the Charge mode, hydrogen is supplied to the cassette $(\mathrm{MHC})$ from $\mathrm{H}_{2}$ line, via reducer $(\mathrm{R})$. In the Discharge mode, hydrogen is released from the cassette (MHC) to Vent line, via check valve (CV). The evacuation system comprises of a rotary vacuum pump (VP) and a Pirani vacuum sensor (VS).

The $\mathrm{MH}$ cassette is heated and cooled by a water bath circulator $(B C$; controlled circulation flow rate in the range

\footnotetext{
${ }^{2}$ The time from the end of the lead encasing and the start of the final activation of the cassettes varied from 1 day to 1 week.
}

3-7 L/min) connected to the input and output pipelines $(15,16$ in Fig. 2, top). The connections of the water pipelines to the cassette are equipped with K-type thermocouples for the measurement of water temperature at the input (TC1) and output (TC2) of the cassette, respectively. One more K-type thermocouple (TC3) was built in the cassette by attaching, before lead encasing, to the wall of one of $\mathrm{MH}$ containers in the middle.

The parameters logged during the tests included $\mathrm{H}_{2}$ pressure $(P)$ at the entrance to the gas manifold, $\mathrm{H}_{2}$ charge/ discharge flow rate $(F R)$, water temperatures at the input ( $T$ (in)) and output (T(out)) of the cassette, as well as the temperature of $\mathrm{MH}$ container in the cassette $(\mathrm{T}(\mathrm{MH}))$. Also, vacuum $(\mathrm{V})$ was monitored during the evacuation.

The final activation of the cassette included release of argon followed by evacuation to $3 \cdot 10^{-2}$ mbar and introducing $\mathrm{H}_{2}$ at line pressure of 50 bar; all the operations were carried out at the room temperature, without circulation of the heating/ cooling water. Hydrogen absorption in the $\mathrm{MH}$ started immediately testified by maximum $\mathrm{H}_{2}$ flow (FR), $40 \mathrm{NL} / \mathrm{min}$, equal to the upper limit set by mass flow controller (MFC), and gradual increase of the temperature $(\mathrm{T}(\mathrm{MH})$ ). The maximum $\mathrm{H}_{2}$ flow of $40 \mathrm{NL} / \mathrm{min}$ remained unchanged during $40 \mathrm{~min}$ followed by a decrease at $\mathrm{T}(\mathrm{MH})>60^{\circ} \mathrm{C}$ (grown from starting $25{ }^{\circ} \mathrm{C}$ ). After the cooling of the tank was switched on ( $\mathrm{T}$ (in) $\sim 20{ }^{\circ} \mathrm{C}$ ), the maximum flow of the absorbed $\mathrm{H}_{2}$ restored immediately and remained constant during $10 \mathrm{~min}$ followed by a gradual decrease. The total (integrated) amount of $\mathrm{H}_{2}$ absorbed in the cassette during $100 \mathrm{~min}$ of the first $\mathrm{H}_{2}$ charge (when the $\mathrm{H}_{2}$ flow rate decreased below $4 \mathrm{NL} / \mathrm{min}$ ) was of 2.59 $\mathrm{Nm}^{3}$, close to the calculated value of $2.5 \mathrm{Nm}^{3}$. Similar values of the total $\mathrm{H}_{2}$ amount absorbed in/desorbed from the $\mathrm{MH}$ cassette $\left(2.5-2.7 \mathrm{Nm}^{3}\right)$ were observed in the course of the next $\mathrm{H}_{2}$ charge/discharge cycles.

Typical $\mathrm{H}_{2}$ charge performance of the $\mathrm{MH}$ cassette during the following discharge - charge operation cycles is shown in Fig. 5, left. It is seen that at $\mathrm{T}$ (in) $=20^{\circ} \mathrm{C}$ and water flow about 

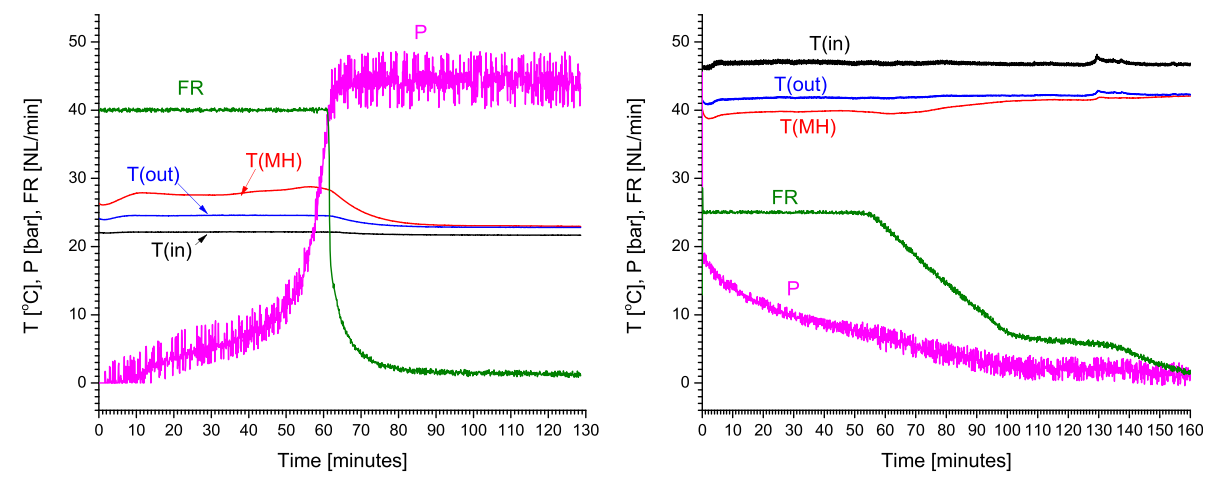

Fig. $5-\mathrm{H}_{2}$ charge (left; water flow at $\mathrm{T}=\mathrm{T}$ (in) $5.2 \pm 0.1 \mathrm{~L} / \mathrm{min}$ ) and discharge (right; water flow at $\mathrm{T}=\mathrm{T}$ (in) $6.9 \pm 0.1 \mathrm{~L} / \mathrm{min}$ ) performance of the MH cassette.

$5 \mathrm{~L} / \mathrm{min}$, the maximum $\mathrm{H}_{2}$ flow rate of $40 \mathrm{NL} / \mathrm{min}^{3}$ can be maintained during $\sim \mathrm{h}$. In doing so, the $\mathrm{H}_{2}$ pressure $(\mathrm{P})$ slowly increases from zero to 10 bar in first 50 min followed by a fast increase up to the line pressure (40-45 bar) during the next 10-15 min. Such behaviour can be explained by an equilibration between the pressure of $\mathrm{H}_{2}$ gas and $\mathrm{H}$ concentration in the $\mathrm{MH}$ material when time dependence of the pressure approximately follows the pressure - composition isotherm (sloping plateau at $\mathrm{P}=3-10 \mathrm{bar} / \mathrm{T}=20^{\circ} \mathrm{C}$; see Fig. 1).

The temperature differences $(\mathrm{T}(\mathrm{MH})-\mathrm{T}(\mathrm{in}))$ and ( $\mathrm{T}$ (out)$\mathrm{T}$ (in)) during $\mathrm{H}_{2}$ absorption at a constant $\mathrm{H}_{2}$ flow rate were about 8 and $5{ }^{\circ} \mathrm{C}$, respectively, followed by a gradual decrease when the $\mathrm{H}_{2}$ flow rate decreased.

Fig. 5, right presents typical $\mathrm{H}_{2}$ discharge performance of the $\mathrm{MH}$ cassette. A summary of the performances measured at different temperatures and flow rates of the heating water is presented in Fig. 6 and Table 1. In all the experiments, the maximum limit of $\mathrm{H}_{2}$ flow rate set by the flow controller was $25 \mathrm{NL} / \mathrm{min}$, or $\sim 20 \%$ higher than a nominal $\mathrm{H}_{2}$ flow rate $(20.83$ $\mathrm{NL} / \mathrm{min}$ ) per one cassette of eight in the hydrogen storage tank (see Section $\mathrm{MH}$ hydrogen storage tank and its integration in fuel cell power module) required to provide the operation of fuel cell stack at a maximum electric power (15 kW).

During $\mathrm{H}_{2}$ discharge (Fig. 5, right), the $\mathrm{H}_{2}$ pressure quickly drops to $\sim 20$ bar followed by a gradual decrease. The maximum $\mathrm{H}_{2}$ flow rate is maintained during 40-60 min followed by almost linear decrease of the flow rate. In doing so, the temperature differences $(\mathrm{T}$ (in) $-\mathrm{T}(\mathrm{MH})$ ) and $(\mathrm{T}$ (in) $-\mathrm{T}$ (out)) during $\mathrm{H}_{2}$ desorption at a constant flow rate were about 6 and 3-4 ${ }^{\circ} \mathrm{C}$, respectively; the $\mathrm{MH}$ temperature then gradually increases approaching the value of $\mathrm{T}$ (out) which remains almost the same.

As it can be seen from Fig. 6 and Table 1, the main factor affecting the $\mathrm{H}_{2}$ discharge performance is the heating temperature whose decrease below $40{ }^{\circ} \mathrm{C}$ results in a significant decrease of $\mathrm{H}_{2}$ amount desorbed at a specific discharge flow rate. This effect becomes more pronounced when the

\footnotetext{
${ }^{3}$ Introducing the upper limit of the $\mathrm{H}_{2}$ flow rate, both in the charge and the discharge modes, was necessary to provide measurements of $\mathrm{H}_{2}$ flow within the range of the used mass flow controller and, accordingly, proper calculation of the total amount of $\mathrm{H}_{2}$ absorbed in or desorbed from the cassette.
}

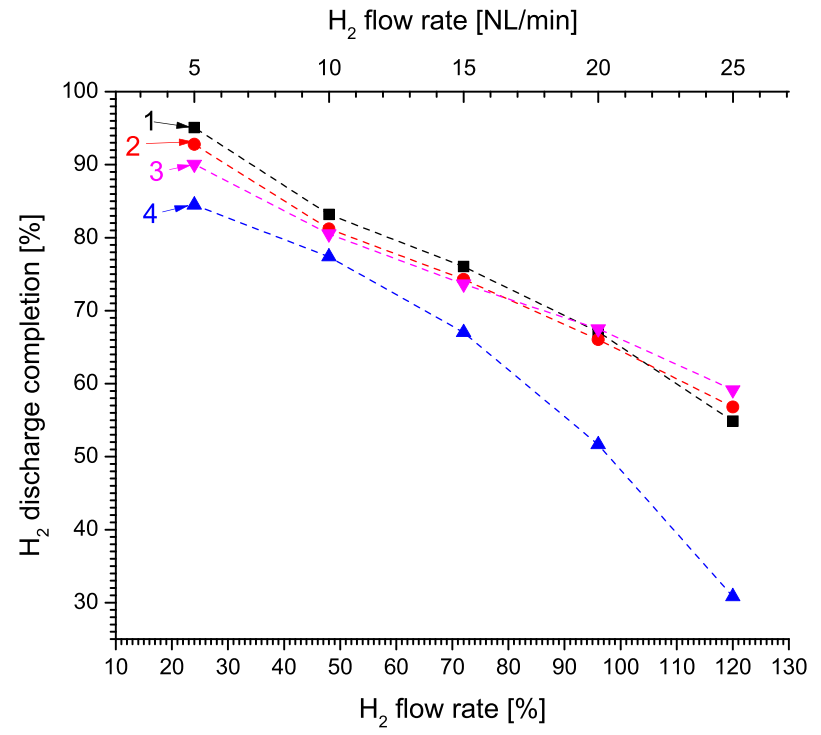

Fig. 6 - Dependence of discharge completion in \% of the full $\mathrm{H}_{2}$ storage capacity $\left(2.5 \mathrm{Nm}^{3}\right)$ of the MH tank on the $\mathrm{H}_{2}$ output flow rate $(100 \%=20.83 \mathrm{NL} / \mathrm{min})$. Experimental conditions of series 1-4 are specified in Table 1.

discharge flow rate increases, particularly, when exceeding 10 $\mathrm{NL} / \mathrm{min}$, or $\sim 50 \%$ of the $\mathrm{H}_{2}$ flow rate necessary for the operation of the fuel cell stack at full capacity. At $\mathrm{T}$ (in) $>45^{\circ} \mathrm{C}$, the discharge performance of the $\mathrm{MH}$ cassette remains almost the same when the decrease of the $\mathrm{H}_{2}$ flow rate from 25 to $5 \mathrm{NL} / \mathrm{min}$

Table $1-\mathrm{H}_{2}$ desorption conditions. Accuracies of the control of the process parameters are $\pm 1{ }^{\circ} \mathrm{C}$ and $\pm 0.1 \mathrm{~L} /$ min, for water input temperature and flow rate, respectively.

Series number (Fig. 6) $\quad$ T(in) $\left[{ }^{\circ} \mathrm{C}\right] \quad$ Water flow rate [L/min]

\begin{tabular}{lll}
\hline 1 & 46 & 3.0 \\
2 & 47 & 6.9 \\
3 & 55 & 6.9 \\
4 & 38 & 6.9 \\
\hline
\end{tabular}




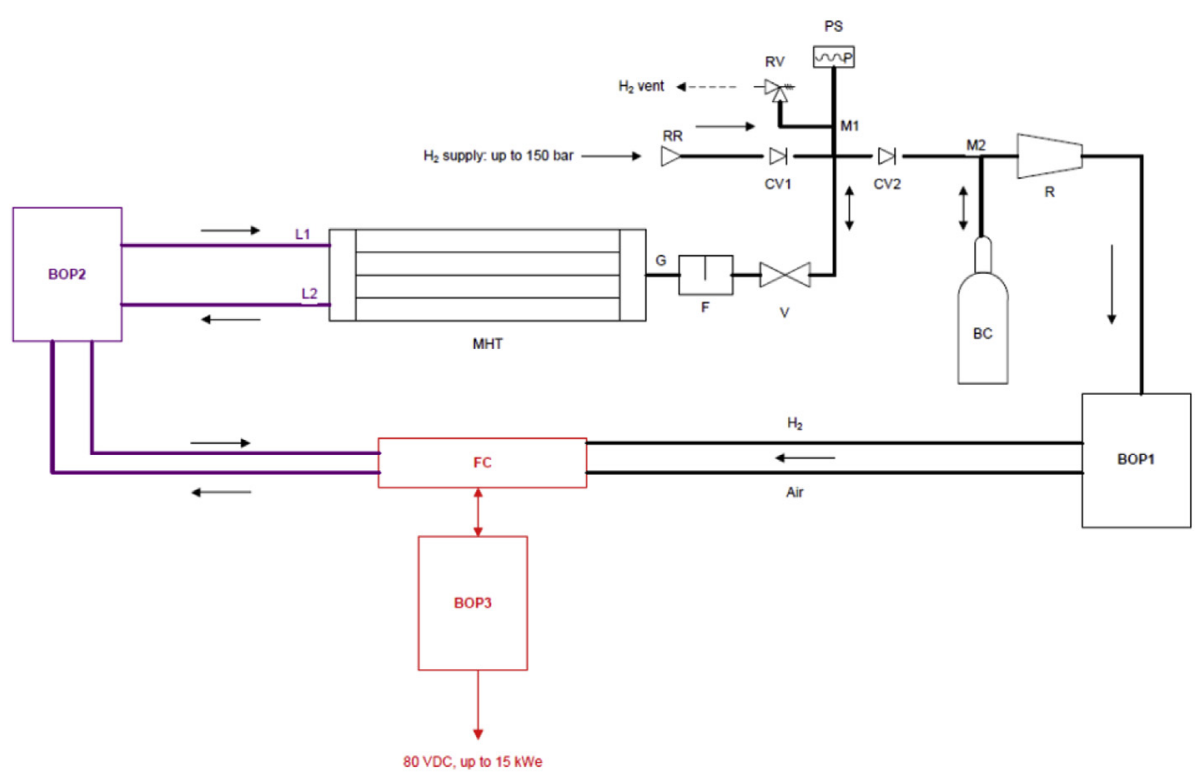

Fig. 7 - Simplified schematic diagram of the integration of the MH tank in forklift power module.

results in the increase of the amount of desorbed hydrogen from $55-60 \%$ to $>90 \%$ of the full hydrogen storage capacity.

\section{MH hydrogen storage tank and its integration in fuel cell power module}

The MH tank comprising of eight lead-encased $\mathrm{MH}$ cassettes described above was integrated in a power module for STILL RX60-30 L electric forklift. The power module jointly developed by HySA Systems and Hot Platinum (Pty) Ltd (South Africa) provides output electric power up to $15 \mathrm{~kW}$ in average (up to $30 \mathrm{~kW}$ peak power) at bus voltage of $80 \mathrm{VDC}$ and has dimensions 840 (L) x 1010 (W) x 777 (H) mm and weight between 1800 and $1900 \mathrm{~kg}$ that corresponds to the admissible weight of the forklift lead acid battery. The power module (see schematic diagram in Fig. 7 and general views in Fig. 8) includes liquid cooled Ballard 9SSL fuel cell stack (FC) whose operation is provided by three BoP systems: system for controlled supply of the fuel $\left(\mathrm{H}_{2}\right)$ and the oxidant (air) (BOP1); stack cooling system (BOP2); and power conditioning and control system (BOP3). The $\mathrm{H}_{2}$ fuel consumption of the power module operating at the maximum power of $15 \mathrm{~kW}$ was estimated as 166.65 NL/min that corresponds to the value of $20.83 \mathrm{NL} / \mathrm{min}$ per one cassette as it was specified in the previous section.

The $\mathrm{MH}$ tank (MHT) is located in the bottom part of the power module and occupies about $1 / 4$ of its inner space (see Fig. 8).

Both gas and heating/cooling liquid pipelines of the eight cassettes are connected in parallel. The common gas pipeline, via auxiliary components, is connected to hydrogen supply port of the gas supply system (BOP1) while the common heating/cooling pipelines are connected to the cooling system (BOP2) of the fuel cell stack.

As shown in Fig. 7, the gas pipeline (G) of the tank (MHT), is connected, via an additional $0.5 \mu$ grade inline filter $(F)$ and a shut-off valve (V) to a gas manifold (M1) connected to a pressure sensor (PS; 0-250 bar) and safety relief valve (RV; set cracking pressure 180 bar) which releases gas to $\mathrm{H}_{2}$ vent pipeline in a case of overpressure. The gas manifold $\mathrm{M1}$, via check valve $C V 1$, is connected to a refuelling receptacle (RR) and, via check valve CV2, to a second gas manifold (M2) connected to a buffer cylinder (BC; $9 \mathrm{~L}$ in the volume) and pressure reducer $(R)$ to supply $\mathrm{H}_{2}$ to the gas supply system of the fuel cell BoP (BOP1) at the pressure of 0.3-0.5 bar gage.

The heating/cooling pipelines $(L 1, L 2)$ of the tank integrated with the cooling system of the fuel cell stack (BOP2) provide heating of the $\mathrm{MH}$ cassettes when the stack is operating, or their cooling during $\mathrm{H}_{2}$ refuelling, by a flow of water/glycol mixture heated by the stack in the operation mode and cooled by a radiator - fan assembly ( $R F$ in Fig. 8 ) in the refuelling mode.

Introducing of the buffer cylinder allows to realise a concept of "distributed hybrid" hydrogen storage and supply system which significantly improves performance of $\mathrm{H}_{2}$ supply from the $\mathrm{MH}$ to the fuel cell stack when its power and, in turn, $\mathrm{H}_{2}$ consumption fluctuate in wide limits [30]. Additionally, presence of check valve (CV2 in Fig. 7) between the $\mathrm{MH}$ tank and the buffer eliminates problem of the system start-up when $\mathrm{H}_{2}$ pressure in the $\mathrm{MH}$ gas manifold (M1 in Fig. 7) after the end of operation $\left(\mathrm{H}_{2}\right.$ desorption at $\left.\mathrm{T} \sim 50{ }^{\circ} \mathrm{C}\right)$ and subsequent cooling down to ambient temperature (e.g. $<20{ }^{\circ} \mathrm{C}$ ) accompanied by $\mathrm{H}_{2}$ absorption in the $\mathrm{MH}$ material can drop below the lower limit of $\mathrm{H}_{2}$ pressure ( $\sim 0.3$ bar gage) necessary for the normal system operation.

Results of preliminary tests of the MH tank integrated in the fuel cell forklift power module showed that the tank can supply $\mathrm{H}_{2}$ to the fuel cell stack at $\mathrm{H}_{2}$ flow rate of $120 \mathrm{NL} / \mathrm{min}^{4}$ for $>2 \mathrm{~h}$ that corresponds to the total amount of supplied hydrogen of $>14.4 \mathrm{Nm}^{3}$, or $>72 \%$ of the full hydrogen storage

\footnotetext{
${ }^{4}$ Up to $170 \mathrm{NL} / \mathrm{min}$ during $>1 \mathrm{~h}$.
} 


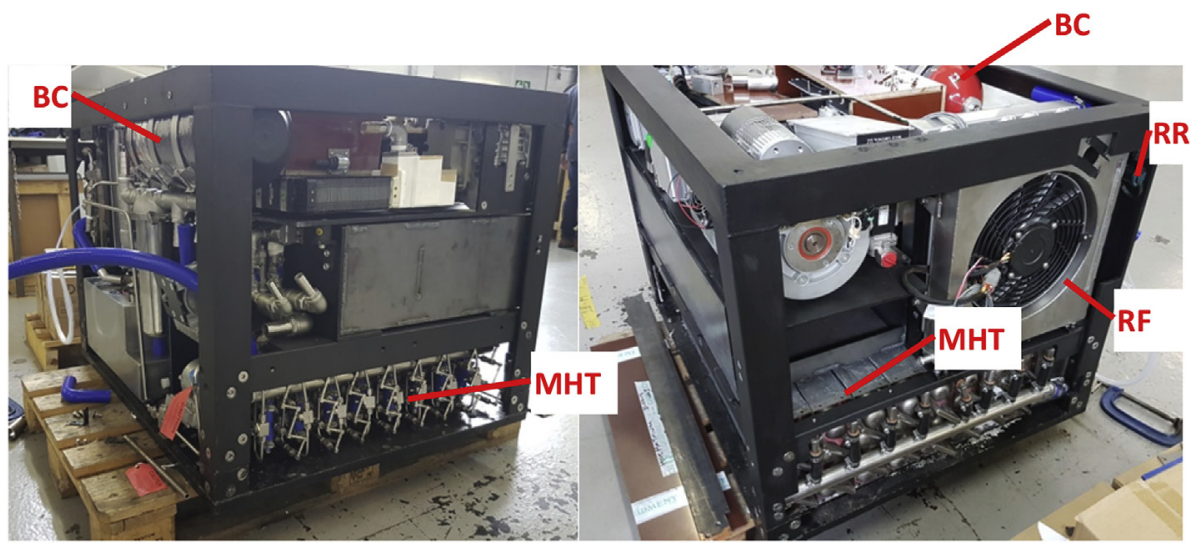

Fig. 8 - MH tank installed in the forklift power module.

capacity of the tank. The $\mathrm{H}_{2}$ flow rate of $120 \mathrm{NL} / \mathrm{min}$ can provide the stack operation at the average power about $11 \mathrm{kWe}{ }^{5}$ The refuelling time of the $\mathrm{MH}$ tank at the ambient temperature between 15 and $20^{\circ} \mathrm{C}$ is about $15-20$ min that is similar to the earlier reported performance of the "distributed hybrid" hydrogen storage system on-board electric forklift with commercial fuel cell power module and $\mathrm{MH}$ extension tank which used similar water-cooled $\mathrm{MH}$ containers [10]. At the same time, due to the use of a more stable $\mathrm{MH}$ material in this work as compared to the material used in Ref. [10], the maximum $\mathrm{H}_{2}$ dispensing pressure could be lowered from 185 to 100-150 bar.

A brief comparison of features and performances of hydrogen storage tank developed in this work and hydrogen storage tanks for the same electric forklift (RX60-30 L, STILL $\mathrm{GmbH}$ ) equipped with commercial fuel cell power module (GenDrive 1000 160X-80CEA; Plug Power Inc.) is presented in Table 2. It can be seen that the combination of the CGH2 and $\mathrm{MH}$ hydrogen storage implementing the "distributed hybrid" solution [30] significantly lowers the refuelling pressure at a similar hydrogen storage capacity.

Further increase of fraction of $\mathrm{H}_{2}$ stored in the $\mathrm{MH}$ results in the further decrease of the refuelling pressure at the same storage capacity, together with a significant, in $\sim 5$ times, decrease of the system volume. Hydrogen storage systems utilising "low-temperature" intermetallic hydrides add weight to the whole on-board power supply system, especially when applying lead encasing procedure described in this work. It is very important for heavy-duty utility vehicle (e.g. forklift) applications where high weight is required for the safe operation.

Due to necessity of dissipation of large amount of heat generated in the $\mathrm{MH}$ in the course of system refuelling with $\mathrm{H}_{2}$, the refuelling time of the $\mathrm{MH}$ hydrogen storage systems is longer than for the CGH2 ones. However, the increase of refuelling time for $\mathrm{MH}$ systems with optimised thermal management is not very dramatic. Moreover, the slower

\footnotetext{
${ }^{5}$ At optimal (towards the increase of stack fuel efficiency) operating conditions. The optimisation of the fuel supply and purging strategy to reduce $\mathrm{H}_{2}$ consumption and increase the efficiency is in progress.
}

refuelling allows to significantly reduce overheating of the supplied $\mathrm{H}_{2}$ thus eliminating necessity of its deep pre-cooling which takes about $10 \%$ of the capital costs of the hydrogen refuelling infrastructure [32]. Instead, the refuelling of $\mathrm{MH}$ tanks requires their cooling to near-ambient temperatures which can be achieved by simple solutions at the refuelling site and/or in the tank itself.

Since hydrogen desorption from the "low-temperature" $\mathrm{MH}$ requires less than $45 \%$ of the heat released during the operation of low-temperature fuel cells (e.g. PEMFC) consuming the released $\mathrm{H}_{2}$ [7], the $\mathrm{MH}$ systems can provide $\mathrm{H}_{2}$ supply to the fuel cell stack which is enough for its operation at the maximum power (see last row of Table2,6).

In summary, partial or complete replacement of the CGH2 hydrogen storage system on-board heavy-duty fuel cell utility vehicles (including forklifts) with the $\mathrm{MH}$ one brings a number of benefits including decrease of the refuelling pressure thus improving operation safety and lowering costs for the refuelling infrastructure. High weight and compactness of the $\mathrm{MH}$ based hydrogen storage system developed in this work will also allow to reduce the space occupied by a ballast in this kind of vehicles thus adding flexibility to the layout of other components (FC stack + BoP) of the fuel cell power modules which can be further improved towards facilitation of their assembling and service.

The remaining problems planned to be solved at the later stage include (i) further decrease of the refuelling pressure, (ii) the increase of useable (per unit volume) hydrogen storage capacity and (iii) lowering the system cost of which as low as $<10 \%$ is for the $\mathrm{MH}$ material while the remaining costs have to be incurred for the $\mathrm{MH}$ containers and other custom-made system components. Solution of the problems (i) and (ii) will be achieved by the optimisation of $\mathrm{MH}$ material while the cost reduction (iii) can be achieved by the advancement of

\footnotetext{
${ }^{6}$ CGH2 systems are characterized by virtually unlimited rate of the $\mathrm{H}_{2}$ release. The lower value of maximum $\mathrm{H}_{2}$ supply flow rate from CGH2 specified in Table 2 is explained by the lower stack power during VDI-60 tests because of reducing, due to safety reasons, the load from the required 3 to 2.5 tonnes [10].
} 
Table 2 - Features and performances of hydrogen storage tanks for fuel cell forklift.

Characteristic

\begin{tabular}{|c|c|c|c|c|}
\hline \multicolumn{2}{|l|}{ Maximum refuelling pressure [bar] } & 350 & 185 & 150 \\
\hline \multicolumn{2}{|l|}{ Minimum operating pressure [bar] } & 13.5 & 13.5 & 4 \\
\hline \multicolumn{2}{|l|}{ Number of MH containers ${ }^{\mathrm{a}}$} & - & 20 & 40 \\
\hline \multicolumn{2}{|c|}{ Total weight of power module and MH tank installed in the forklift ${ }^{\mathrm{b}}$} & 1600 & 1784 & 1830 \\
\hline \multirow[t]{3}{*}{ System inner volume $[\mathrm{L}]$} & CGH2 & 74.2 & 74.2 & 9.0 \\
\hline & $\mathrm{MH}$ & - & $7.4^{c}$ & $14.8^{c}$ \\
\hline & Total & 74.2 & 81.6 & 23.8 \\
\hline \multirow{3}{*}{ Useable $\mathrm{H}_{2}$ storage capacity [kg] } & CGH2 & 1.7 & 0.9 & 0.1 \\
\hline & $\mathrm{MH}$ & - & 0.9 & 1.7 \\
\hline & Total & 1.7 & 1.8 & 1.8 \\
\hline \multicolumn{2}{|l|}{ Refuelling time [min] } & $3-5$ & $6-15$ & $15-20$ \\
\hline \multicolumn{2}{|l|}{ Maximum $\mathrm{H}_{2}$ supply flow rate $[\mathrm{NL} / \mathrm{min}]^{\mathrm{d}}$} & 130 & 170 & 170 \\
\hline
\end{tabular}

manufacturing technology of the system components to enable their mass production.

Further details about the design and operation of the developed fuel cell power module with the integrated $\mathrm{MH}$ hydrogen storage tank described in this work will be published in a due course.

\section{Conclusions}

- New engineering solution of a metal hydride hydrogen storage tank for fuel cell utility vehicles which combines compactness, adjustable high weight, as well as good dynamics of hydrogen charge/discharge has been developed.

- The developed MH tank comprises plurality of MH cassettes made as assemblies of externally heated/cooled $\mathrm{MH}$ containers filled with an $\mathrm{AB}_{2}$-type hydrogen storage material and staggered together with the heating/cooling tubes; the assembly is encased in molten lead followed by the solidification of the latter.

- The MH tank has been successfully integrated in a prototype fuel cell power module for electric forklift.

- Replacement of the CGH2 hydrogen storage system onboard heavy-duty fuel cell utility vehicles with the $\mathrm{MH}$ one brings a number of benefits including improvement of operation safety and lowering costs for the refuelling infrastructure.

\section{Acknowledgements}

This work is funded by the Department of Science and Technology (DST) within the HySA Programme (HySA Systems projects KP3-S02 and KP6-S03), and Impala Platinum Limited; South Africa. Since end 2017, the international collaboration activities within this work are supported by the EU Horizon 2020 program; Grant Agreement 778307 HYDRIDE4MOBILITY - H2020-MSCA-RISE-2017.

ML and MWD acknowledge NRF support, grant numbers 109092 (ML) and 116278 (MWD).

The authors also acknowledge engineering and technical support from Hot Platinum (Pty) Ltd (South Africa), in the development and assembling of the forklift fuel cell power module.

\section{R E F E R E N C E S}

[1] Satyapal S, Petrovic J, Read C, Thomas G, Ordaz G. The U.S Department of energy's national hydrogen storage project: progress towards meeting hydrogen-powered vehicle requirements. Catal Today 2007;120:246-56.

[2] Godula-Jopek A. Hydrogen storage options including constraints and challenges. In: Godula-Jopek A, editor. Hydrogen production by electrolysis. 1st ed. Wiley-VCH Verlag GmbH \& Co. KGaA; 2015. p. 273-309.

[3] Millet P. Hydrogen storage in hydride-forming materials. In: Basile A, Iulianelli A, editors. Advances in hydrogen production, storage and distribution. Elsevier; 2014. p. 368-409. https://doi.org/10.1533/9780857097736.3.368.

[4] Niaz S, Manzoor T, Pandith AH. Hydrogen storage: materials, methods and perspectives. Renew Sustain Energy Rev 2015;50:457-69.

[5] Viswanathan B. Hydrogen storage. In: Energy sources, fundamentals of chemical conversion processes and applications. Elsevier; 2017. p. 185-212. https://doi.org/ 10.1016/B978-0-444-56353-8.00010-1.

[6] Lototskyy M, Yartys VA. Comparative analysis of the efficiencies of hydrogen storage systems utilising solid state H storage materials. J Alloy Comp 2015;645:S365-73.

[7] Lototskyy MV, Tolj I, Pickering L, Sita C, Barbir F, Yartys V. The use of metal hydrides in fuel cell applications. Prog Nat Sci 2017;27:3-20. 
[8] Bellosta von Colbe J, Ares J-R, Barale J, Baricco M, Buckley C, Capurso G, et al. Application of hydrides in hydrogen storage and compression: achievements, outlook and perspectives. Int J Hydrogen Energy 2019;44:7780-808.

[9] Lototskyy MV, Tolj I, Davids MW, Klochko YV, Parsons A, Swanepoel D, et al. Metal hydride hydrogen storage and supply systems for electric forklift with low-temperature proton exchange membrane fuel cell power module. Int J Hydrogen Energy 2016;41:13831-42.

[10] Lototskyy MV, Tolj I, Parsons A, Smith F, Sita C, Linkov V. Performance of electric forklift with low-temperature polymer exchange membrane fuel cell power module and metal hydride hydrogen storage extension tank. J Power Sources 2016;316:239-50.

[11] Jorgensen SW. Hydrogen storage tanks for vehicles: recent progress and current status. Curr Opin Solid State Mater Sci 2011;15:39-43.

[12] Plug power ${ }^{\circledR}$ GenDrive series 1000; http://www.plugpower. com.

[13] HyPX'M POWER PACKS; http://www.hydrogenics.com/.

[14] Technical specifications: H2Drive ${ }^{\circledR}$. Unlimited and zero emission power for forklifts; http://www.h2logic.com.

[15] Keränen TM, Karimäki H, Viitakangas J, Vallet J, Ihonen J, Hyötylä P, et al. Development of integrated fuel cell hybrid power source for electric forklift. J Power Sources 2011;196:9058-68.

[16] Valicek P, Fourie F. Fuel cell technology in underground mining. In: 6th int. Platinum conf, 'Platinum-Metal for the future'. The Southern African Institute of Mining and Metallurgy; 2014. p. 325-32.

[17] Iwaki T, Itou K, Matsumoto H, Suzuki H, Shibata J, Uematsu N. Hydrogen engine system with metal hydride container. Patent US. 1992. 5082048.

[18] Rendina DD. Hydrogen hydride keel. Patent US. 1995. 5445 099.

[19] Pfeiffer N, Fromme G, Leifert T. Industrial truck with a hydrogen tank. Patent EP. 2005. 1215163 B1.

[20] Gregory BA, Medwin S, Bordwell B, Field M, Banko II JE. Material handling vehicle including integrated hydrogen storage, patent application US. 2009. 0166110 A1.

[21] Narvaez A. Low cost, metal hydride based hydrogen storage system for forklift applications (phase II). US DOE
Ann Merit Rev Meeting; June 18, 2014. Project ST 095; https://www.hydrogen.energy.gov/pdfs/review14/st095_ narvaez_2014_p.pdf.

[22] Lototskyy M, Davids MW, Pollet BG, Linkov V, Klochko Y. Metal hydride bed, metal hydride container, and method for the making thereof, patent application WO, 2015, 189758 A1.

[23] Lototskyy M, Klochko Y, Tolj I, Davids MW, Parsons A, Sita C, et al. Metal hydride hydrogen storage arrangement for use in a fuel cell utility vehicle and method of manufacturing the same, Patent Application UK 1806840, 3; 2018.

[24] Lototskyy MV, Davids MW, Tolj I, Klochko YV, Satya Sekhar B, Chidziva S, Smith F, Swanepoel D, Pollet BG. Metal hydride systems for hydrogen storage and supply for stationary and automotive low temperature PEM fuel cell power modules. Int J Hydrogen Energy 2015;40:11491-7.

[25] Pickering L, Lototskyy MV, Davids MW, Sita C, Linkov V. Induction melted $\mathrm{AB}_{2}$-type metal hydrides for hydrogen storage and compression applications. Mater Today: Proc 2018;5:10470-8.

[26] Lototskyy MV. New model of phase equilibria in metal hydrogen systems: features and software. Int J Hydrogen Energy 2016;41:2739-61.

[27] Rodriguez Sanchez A, Klein H-P, Groll M. Expanded graphite as heat transfer matrix in metal hydride beds. Int J Hydrogen Energy 2003;28:515-27.

[28] Dieterich M, Pohlmann C, Bürger I, Linder M, Röntzsch L. Long-term cycle stability of metal hydride-graphite composites. Int J Hydrogen Energy 2015;40:16375-82.

[29] SANS. (Edition 2), South African National Standard, "Categorization and conformity assessment criteria for all pressure equipment.". 2012.

[30] Lototskyy M, Tolj I, Davids MW, Bujlo P, Smith F, Pollet BG. "Distributed hybrid" $\mathrm{MH}-\mathrm{CGH} 2$ system for hydrogen storage and its supply to LT PEMFC power modules. J Alloy Comp 2015;645:S329-33.

[31] Service manual: GenDrive series 1000 160x-80CEA, document No: 096136. Plug Power Inc.; 2014.

[32] Elgowainy A, Reddi K, Lee D-Y, Rustagi N, Gupta E. Technoeconomic and thermodynamic analysis of pre-cooling systems at gaseous hydrogen refuelling stations. Int $J$ Hydrogen Energy 2017;42:29067-79. 